\title{
The impact of Covid-19 on ethnicity, minorities and immigrants: Are we all in the same ship?
}

\section{Covid-19'un etnisite, azınlıklar ve göçmenler üzerine etkisi: Hepimiz aynı gemide miyiz?}

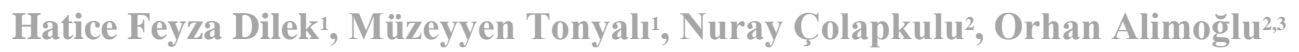

İstanbul Medeniyet Üniversitesi, Tıp Fakültesi, Dönem 6 Öğrencisi, İstanbul, Türkiye

İstanbul Medeniyet Üniversitesi, Tıp Fakültesi, Genel Cerrahi Anabilim Dalı, İstanbul, Türkiye

İstanbul Medeniyet Üniversitesi, Afrika Sağlı Calıșmaları Uygulama ve Araștırma Merkezi (MASAM), İstanbul, Türkive

Corresponding author: Orhan Alimoğlu, MD., İstanbul Medeniyet Üniversitesi, Tıp Fakültesi, Genel Cerrahi Anabilim Dalı, İstanbul, Türkiye

E-mail: orhanalimoglu@gmail.com

Received/Accepted: August 02, 2020 / September 18, 2020

Conflict of interest: There is not a conflict of interest.

\begin{abstract}
SUMMARY
Covid-19, which has caused a severe pandemic to the whole world since December 2019, continues to spread while collapsing health systems, societies and economies; while leaving controversy behind. As the coronavirus spread globally demographics of the infected are identified and current evidences point ethnical "bias" of not only to the relatively higher infection rates among minority groups, but also to the severity of the clinical course. In communities where sanitation, prevention, and determined treatment standards for the current situation are not met, the results of the pandemic can be far more devastating.
\end{abstract}

Keywords: Covid-19, ethnicity, minorities, immigrants, mortality

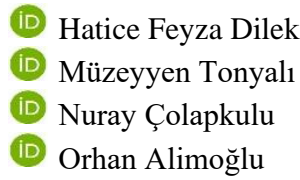

H.F.D. 0000-0002-4878-9552

M.T. 0000-0002-7087-3558

N.Ç. 0000-0002-3033-8702

O.A. 0000-0003-2130-2529

\section{ÖZET}

Aralık 2019'dan bu yana tüm dünyada ağır bir salgına neden olan Covid-19, sağlık sistemleri, toplumlar ve ekonomiler çökerken, arkasında tartışmalar bırakarak yayılmaya devam etmektedir. Covid-19 küresel olarak yayıldıkça, enfekte olanların demografik özellikleri belirlendikçe ve mevcut kanıtlar, yalnızca azınlık grupları arasındaki nispeten yüksek enfeksiyon oranlarına değil, aynı zamanda klinik seyrin ciddiyetine yönelik etnik "yanlılığı" işaret etmektedir. Tüm bu bilgilerin 1şı̆̆ında, mevcut durum için belirlenmiş tedbir ve tedavi standartlarının karşılanmadığı topluluklarda, pandeminin sonuçları çok daha yıkıcı olabilmektedir.

Anahtar sözcükler: Covid-19, etnisite, azınlıklar, göçmenler

\section{INTRODUCTION}

In December 2019, Coronavirus Disease 2019 (Covid-19) appeared in Wuhan, Hubei province of China. As the disease continued to spread rapidly, the disease turned into a pandemic and became a major global threat ${ }^{1}$. Susceptible populations are males and older adults with co-morbidities such as hypertension, obesity, diabetes, chronic lung diseases, and also other possible susceptible factors are immigration, ethnicity and racial minority groups ${ }^{1,2}$. In this context, determination of whether the course of the disease is different in minority groups will contribute to reorganization of the countries' health care policies during ongoing and future epidemic management. Therefore we aimed 
to birefly review the reports that demonstrate the relationship between ethnicity-race characteristics, imigrants and Covid-19.

As the coronavirus spread globally demographics of the infected were identified and current evidences point ethnical "bias" of not only to the relatively higher infection rates among minority groups, but also to the severity of the clinical course. African-American, American Indian, people who have low-income and live or work in crowded environments and minorities are at inreased risk of getting Covid- $19^{3}$. What is behind this disparity? In studies investigating population level risks, Black race, obesity, gender and age are reported to be among the risk factors for severe infection ${ }^{2,4,5}$. Although there is a high risk of developing serious infections due to these parameters, it is difficult to make an inference without evaluating the additional features of these groups. In order to reach the accurate conclusion among groups that contain risk factors but have different social conditions such as workplace, house environment, access to health systems and individual behavior; modifiable and nonmodifiable parameters should be evaluated together. According to a study presenting with fever, elevated levels of C-reactive protein and procalcitonin are more common in Black patients ${ }^{6}$. Despite the claims that Black or Indigenous communities have infection-prone immunity, the main factors that make these communities vanurable are social and environmental factors and higher incidence of other communicable diseases such as $\mathrm{TB}^{7,8}$. According to these findings, it can be concluded that the immune response to inflammation is different in Blacks; however, it is impossible to infer whether it is an ethnically linked immune response or an immune response modulated by environmental factors.

Although older age has been identified as a risk factor in previous studies in terms of the risk of developing severe infection, hospitalization at younger ages in Blacks compared to White was detected. For instance, hospitalization between the ages 18-49, for Black and White poeople were $39.1 \%$ and $22.1 \%$ respectively. Advenced age, above 65 , has an opposite effect as $53.7 \%$ in the context of hospitalization for White and $32.7 \%$ for Black patients ${ }^{9}$.

According to a study conducted to analyse the rates of Covid-19 infection and mortalitiy by ethnicity, Hispanic (652) and Black (530) people had higher rates of Covid-19 infection per 100,000, compared to White (913) population in US. Additionally, same study revealed increased mortality rates among Blacks, compared to Hispanic and White patients ${ }^{10}$. Furthermore, as of May 1, 2020, 34\% of serious Covid-19 patients were reported to be ethnic minor groups in the UK ${ }^{11}$. Different mortality rates on a state-by-population basis with equivalent Black population density may indicate inadequate and disproportionate health care and deeper socioeconomic deficits for ethnic minorities ${ }^{12}$. Therefore, the mortality rates of individuals of different ethnic backgrounds may be related to their access to health services and the inadequacy of medical care that was provided specifically for them.

Another problem to address is immigrants and their living conditions. Immigrants were heavily affected, as a result of closed borders of all countries around the world and ongoing travel restrictions. The number of registered Syrian refugees in Turkey under temporary protection is almost 3.6 million people as of May 15, $2020{ }^{13}$. Establishing health care systems were challenging for Turkey where millions of people are hosted and due to lacking of multiple factors, such as finance, institutes and language. According to a study conducted via questionarre among 879 Syrian refugees, $2 \%$ of the respondents claimed comfirmed Covid-19 infection ${ }^{14}$. In many immigrant camps, there are difficulties in following the hygiene rules proposed under the pandemic, and in some camp areas, thousands of immigrants, including individuals with chronic diseases, share one water tap and cannot access the hygiene materials required for sanitation ${ }^{15,16}$. Thus, the transmission rates may be higher in immigrant camps where social distance is the most difficult to maintain. In addition, with the fear of getting deported, undocumented immigrants are afraid to seek medical help despite presenting the symptoms of the disease ${ }^{17,18}$. It is important that immigrants without health insurance are included in national health systems during this period. In these camps where standards are not met, regular health examinations can be performed, and positive tested individuals can be isolated by performing filiation when suspicious individuals are detected.

Racial and ethnic disparity is a multifactorial, intertwined phenomenon. Elaborate genetic and environmental factor related researches are crucial to recieve accurate answers. In many countries, adequate measures have not been taken to encounter this pandemic, so it was inevitable for such a pandemic to devastate the medical resources and intensive care capacities. Consequently, minorties took the haviest impact and the fall. More time and data from across the globe are required to see a clearer and bigger picture of the Covid-19's 
almost revealing effect of biases within our not only health care system but on our implementation of basic human rights.

\section{REFERENCES}

1. He F, Den, Y, Li W: Coronavirus disease 2019: What we know? J Med Virol. 2020; $1-7$

2. Ho FK, Celis-Morales CA, Gray SR, katikireddi SV, Niedzwiedz CL, Hastie C, Lyall DM, Ferguson LD, Berry C, Mackay DF, Gill JMR, Pell JP, Sattar N, Welsh PI: Modifiable and nonmodifiable risk factors for COVID-19: results from UK Biobank. medRxiv 2020; published online May 2.

3. Raifman MA, Raifman JR: Disparities in the population at risk of severe illness from COVID-19 by race/ethnicity and income. Am J Prev Med 2020;S749-3797 (20)30155-0. [published online ahead of print, 2020 Apr 27].

4. de Lusignan S, Dorward J, Correa A, Jones N, Akinyemi $\mathrm{O}$, Amirthalingam $\mathrm{G}$, Andrews N, Byford R, Dabrera G, Elliot A, Ellis J, Ferreira F, Lopez Bernal J, Okusi C, Ramsay M, Sherlock J, Smith G, Williams J, Howsam G, Zambon M, Joy M, Hobbs FDR: Risk factors for SARS-CoV-2 among patients in the Oxford Royal College of General Practitioners Research and Surveillance Centre primary care network: a cross-sectional study. Lancet Infect Dis 2020 May 15:S1473-3099(20)30371-6.

5. The OpenSAFELY Collobrative, Williamson E, Walker AJ, Bhaskaran KJ, Bason S, Bates C, Morton CE, Curtis HJ, Mehrkar A, Evans D, Inglesby $\mathrm{P}$, Cockburn J, Mcdonald HI, MacKenna B, et al.: OpenSAFELY: factors associated with COVID-19-related hospital death in the linked electronic health records of 17 million adult NHS patients. medRxiv 2020; published online May 7.

6. Price-Haywood E, Burton J, Fort D, Seoane L. Hospitalization and mortality among black patients and White patients with Covid-19. N Eng J Med 2020: NEJMsa2011686

7. Ignacio Amigo: Indigenous communities in Brazil fear pandemic's impact. Science 2020;368(6489):352

8. Laurencin CT, McClinton A: The COVID-19 Pandemic: a Call to Action to Identify and
Address Racial and Ethnic Disparities. J Racial Ethn Health Disparities 2020;7(3):398-402

9. https://www.cdc.gov/coronavirus/2019ncov/covid-data/covidview/index.html (Accessed on 15 May 2020)

10. Yeboa-Anyane A, Sato T, Sakuraba A: Racial disparities in COVID-19 deaths reveal harsh truths about structural inequity in America. J Intern Med 2020; (published on 25 May 2020)

11. Bhala N, Curry G, Martineau A, Agyemang C, Bhopal: Sharpening the global focus on ethnicity and race in time of COVID-19. Lancet 2020;395(10238): 1673-76

12. Ji Y, Ma Z, Peppelenbosh MP, Pan Q. Potential association between COVID-19 mortality and healthcare resource availability. Lancet Glob Health 2020; 8(4):e480

13. Ministery of Interior, Directorate General of Migration Management, Temporary Protection Statistics, https://en.goc.gov.tr/temporaryprotection27_(Accessed on 1 June 2020)

14. Impact of the Covid-19 outbreak on Syrian refugees in Turkey. Relief International https://reliefweb.int/sites/reliefweb.int/files/res ources/76504.pdf (Accessed on 1 June 2020)

15. COVID-19: BBC Panorama investigates the squalid Greek refugee camps risking virus outbreak

https://www.msf.org.uk/article/covid-19-bbcpanorama-investigates-squalid-greek-refugeecamps-risking-virus-outbreak (Accessed on 18 May 2020)

16. Hopman J, Allegranzi B, Mehtar S: Managing COVID-19 in Low- and Middle-Income Countries. 2020;10.1001/jama.2020.4169

17. Kluge HHP, Jakab Z, Bartovic J, D'Anna V, Severoni S: Refugee and migrant health in the COVID-19 response. Lancet 2020;395(10232):1237-39.

18. Undocumented migrants dying of coronavirus because they're too afraid to seek help, MPs and charities warn. https://www.independent.co.uk/news/uk/homenews/coronavirus-undocumented-migrantsdeaths-cases-nhs-matt-hancock-a9470581.html (Accessed on 18 May 2020) 